\title{
CONVENTIONAL AND MOLECULAR STUDY OF Babesia spp. OF NATURAL INFECTION IN DRAGGING HORSES AT SOME AREAS OF BAGHDAD CITY, IRAQ
}

\author{
A. A. Faraj \\ B. F. Hade \\ A. M. Al- Amery
}

*Department of Parasitology, College of Veterinary Medicine, University of Baghdad, Iraq Email:aazhar888@yahoo.com

ABSTRACT

The present study was planned to investigate equine babesiosis in dragging horses in Baghdad city, Iraq by using microscopical and molecular (PCR) techniques. 150 blood samples of horses examined for Theileria equi and Babesia caballi. $16.66 \%(25 / 150)$ were positive by microscopic examination. No significant difference was observed in infection rates between male and female horses and among different age groups. The result showed that PCR method has high rate of infection36\% (9/25). Nine positive PCR products were sequenced and deposited in Genebank data base for first time in Iraq, phylogenic analysis demonstrated that 5 sequences belongs to $T$. equi (MK350319, MK346272, MK346273, MK346274 and MK36275), while 4 sequence (MK346276, MK346277, MK346278 and MK350318) belongs to B. caballi, and mounted a low genetic variation 0.035 and 0.05 respectively, among other comparison isolates. In conclusion PCR technique followed by phylogenic tree analysis a reliable methods for epidemiological, diagnosis and identification of genetic variants studies.

Key word: molecular techniques, Theileria equi, Babesia caballi, horses, Iraq.

الاراسة التقليدية و الجزيئية لطفيلي . Babesia spp للعدوى الطبيعية في خيول الجر في بعض مناطق مدينة بغداد ، العرلق

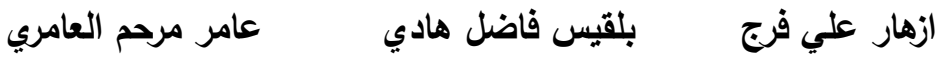

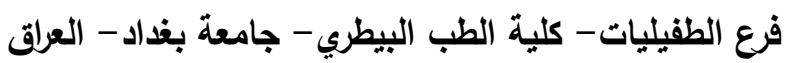

المستخلص

صممت الدارة الحالية للتحري عن داء الكمثريات في خيول الجر في مدينة بغداد، العرلق. باستخدام الفحص المجهري و

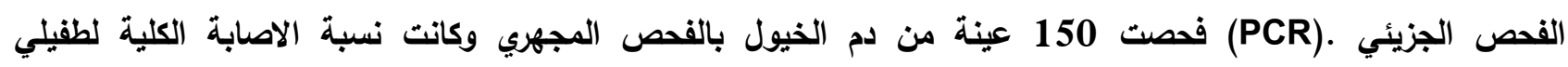
16.66 Babesia spp.

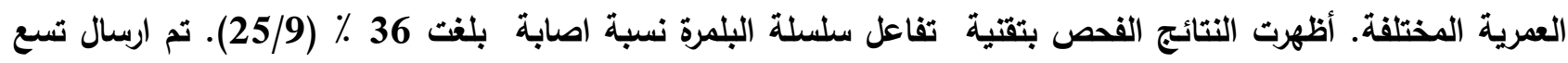
عزلات موجبة باستخدام الفحص الجزيئي و إيداعها في قاعدة بيانات بنك الجينات العالمي، حيث أظهرت نتائج شجرة التطور

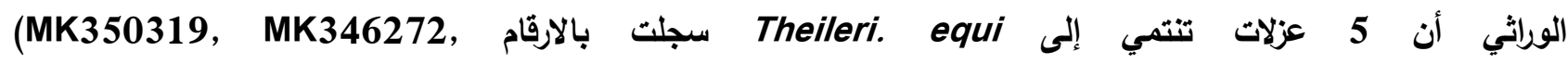

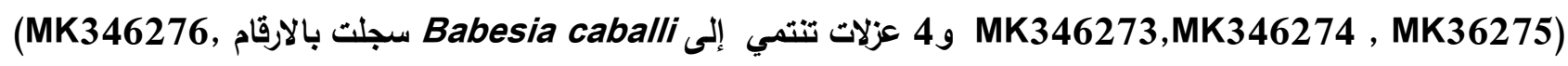
MK346277, MK346278 and MK350318) منخفضًا 0.035 و 0.05 على التوالي مقارنة بالعزلات الأخرى. نستخلص ان تقنية PCR وتحليل شجرة التطور الوراثي

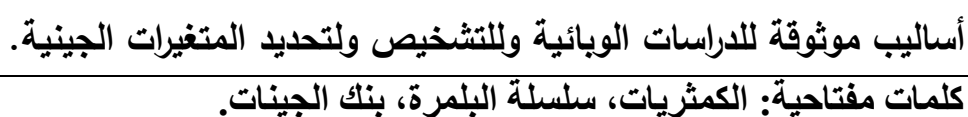




\section{INTRODUCTION}

Equine babesiosis as the most important blood parasitic tick-borne disease affecting equids (horse, pony, donkey, and mule), it is produced by Babesia spp. (B. caballi and Theileria equi ) protozoan $(12,13)$. Babesia species are transmitted by tick species belong to the genera Hyalomma, Rhipicephalus and Boophilus (27). The disease of equine babesiosis characterized is by fever, pale mucous membranes, icterus and hemoglobinuria leading to eventual loss of condition of the animal $(23,28)$. Causative agent of equine babesiosis can be detected by microscope; however, this technique has the disadvantage of being having low sensitivity, mostly in horses with low parasitemia (14). Diagnosis of piroplasms using molecular technique is very necessary for $B$, caballi and $T$. equi, by PCR especial employment which overcome conventional and serological techniques problems, since it was reliable diagnosis method for cryptic species $(2,17)$. Aimed of this study is Babesia spp detection in horses by using molecular technique followed by sequencing and phylogenic tree analysis of the 18s rRNA gene.

\section{MATERIALS AND METHODES}

\section{Samples collection}

150 blood samples were collected randomly from dragging horses in some areas of Baghdad city, during from January to July 2018, blood samples was taken from the jugular vein from horses of different breed, ages and of sexes, $5 \mathrm{ml}$ blood samples were collected from each animal and was divided into two parts, the first $(2 \mathrm{ml})$ of the blood used immediately for blood smears stained with Giemsa stain, and the rest (2-3ml )of blood was collected in EDTA tube, for DNA extraction. All samples were transport in ice box to the laboratory - Veterinary Medicine College- University of Baghdad.

\section{Microscopic examination}

Thin smears of the blood smears were prepared from the first part $2 \mathrm{ml}$ of blood samples collected from animals according to (9).

\section{Molecular diagnosis method} isolation of genomic DNA from whole blood The second part of blood (2-3 ml) collected in EDTA tube is used to isolate the genomic DNA from the whole blood samples. 25 blood samples (collected randomly from 150 blood sample examined previously by microscope) used in DNA extraction purpose according to commercial purification method described by G- spin DNA extraction kit cat.no. 17045 (INTRON biotechnology, Korya). A final DNA sample of $50 \mu \mathrm{l}$ was eluted and stored at $-20{ }^{\circ} \mathrm{C}$ until analyzed by PCR. Estimation of the DNA Concentration and Purity carried out according to a method presented by Sambrook et al. (20). Red save stained $0.8 \%$ agarose gel applied for detected DNA quality and integrity (11). PCR component performed using two pairs of specific oligonucleotide primers against the gene (18s rRNA) of Babesia spp. in table (1) first primer mentioned by Casati et al. (4) and second primer described by Oosthuizen et al. (16). PCR amplification consist from PCR master mix with a final reaction volume of $(25 \mu \mathrm{L})$, Master Mix $(5 \mu \mathrm{l})$, DNA template $(1.5 \mu \mathrm{l}), \quad(1 \mu \mathrm{l})$ of each

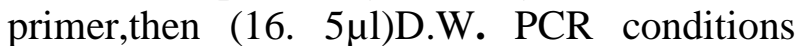
start with initial denaturation $\left(94^{\circ} \mathrm{C}\right.$ for $\left.5 \mathrm{~min}\right)$, denaturation $\left(94^{\circ} \mathrm{C} 45 \mathrm{~min}\right)$, A 35 cycle of annealing $58^{\circ} \mathrm{C}$ for first primer and $60^{\circ} \mathrm{C}$ for second primer for $45 \mathrm{~min}$, extension $\left(72^{\circ} \mathrm{C}\right.$ for $45 \mathrm{~min})$ with final extension of $\left(72^{\circ} \mathrm{C}\right.$ for 5 $\min )$.

Table 1. The primer with their sequence and product size

\begin{tabular}{|llll|}
\hline \multicolumn{1}{|c}{ Primer } & \multicolumn{1}{c}{ Sequence } & Tm( $\left(^{\circ} \mathrm{C}\right)$ & Product size \\
\hline First forward & 5'-GTCTTGTAATTGGAATGATGG $-\mathbf{3}^{\prime}$ & $\mathbf{5 4 . 3}$ & $\mathbf{4 1 1 - 4 5 2 \mathrm { bp }}$ \\
First reverse & 5'-TAGTTTATGGTTAGGACTACG- 3' $^{\prime}$ & $\mathbf{4 9 . 4}$ & \\
Second forward & 5'-GGGTTCGATTCCGGAGAGGG - 3' $^{\prime}$ & $\mathbf{6 0 . 3}$ & $\mathbf{7 5 2}$ bp \\
Second reverse & 5'-CCCGTGTTGAGTCAAATTAAGCCG-3' & $\mathbf{6 0 . 1}$ & \\
\hline
\end{tabular}

Sequencing and phylogenetic analysis

PCR products purified using (INTRON) kit and analyzer (Macrogen) using terminator cycle sequencing and BLAST analysis database (http://blast.ncbi.nlm.nih.gov), edited with (Mega 6) then analyses by (Neighbour Joining Method).

Statistical Analysis: All data were subjected to Statistical Analysis System- SAS 
(2012)(21) . The differences factors were assessed by chi square test.

\section{RESULTS AND DISCUSSION}

Out of 150 blood samples of horses examined for T.equi and B.caballi, $16.66 \%(25 / 150)$ were positive by microscopic examination. The microscopic examination of the blood smear revealed that the Babesia spp. appear in many shapes (round shape and classic tetradforms inside the erythrocyte). The prevalence in males was $14.28 \%$ (10/70), while in females was $18.75 \%(15 / 80)$. No significant difference was observed in prevalence of Babesia spp. infection between female and male, which means female and male are equally affected with Babesia species irrespective of sex. Regarding to age the results revealed that age groups recorded a percentage $15 \%(9 / 60)$ in ages equal or less than four year and $17.77 \%(16 / 90)$ in the ages more than four years significant difference in prevalence was not observed in two age group ( Table 2,3)(Figure1).

Figure 1. Blood smear stained with giemsa of infected horse with Babesia spp.: Round shape and classic tetrad-forms, (maltase cross) and inside the RBC (blue arrow) (X100).

Table 2. Rate of Babesia spp, infection according to horses sexes

\begin{tabular}{|cccc|}
\hline Sex & No. animal examined & No. animal infected & $\%$ \\
\hline Male & 70 & 10 & 14.28 \\
Female & 80 & 15 & 18.75 \\
Total & 150 & 25 & 16.66 \\
Chi-Square $\left(\chi^{2}\right)$ & --- & -- & 0.902 NS \\
& \multicolumn{2}{c}{ NS: Non-Significant. } \\
\hline
\end{tabular}

Table 3. Rate of Babesia spp, infection according to horses age.

\begin{tabular}{|cccc|}
\hline Age/year & No. animal examined & No. animal infected & $\%$ \\
\hline$<4$ years & 60 & 9 & 15.00 \\
$\geq 4$ years & 90 & 16 & 17.77 \\
Total & 150 & 25 & 16.66 \\
Chi-Square $\left(\chi^{2}\right)$ & -- & -- & 0.894 NS \\
& \multicolumn{2}{c}{ NS: Non-Significant. }
\end{tabular}

Present study revealed $16.66 \%$ rate of Babesiosis infection according to the microscopic examination, and this indicate there is Babesia infection distribution on site of study. Present study finding was close accordance with Sumbria et al., (25) in Punjab, in India $14.14 \%$ was prevalence rate of $T$. equi and B. caballi infection. Also with studies of Mahmoud et al. (9) and Ibrahim et al. (8) they reported the prevalence of babesiosis in Egypt was $13.6 \%$ and $18 \%$ respectively. The studies from other countries revealed high prevalence rate like $20.1 \%$ and $41.7 \%$ was reported from Niger state by $(18,19)$. Fluctuation in the prevalence rates might be due to different sample number and variation of environmental conditions that affect both parasites and vectors. In this study no differences were 
observed between horse age and sex with the rate of infection, which is consistent with findings by $(10,19,24)$. These result might be due to high numbers of ticks in this area and continuous exposure of horses to infected ticks (18).

\section{Molecular Assay Results}

Twenty-five blood sample collected randomly from total 150 microscopically examined, were subjected to extracted genomic DNA, the result obtained high DNA concentration range between (100-140 $\mathrm{ng} / \mu \mathrm{l})$ with purity (1.5-1.6) as showed in (Figure 2).

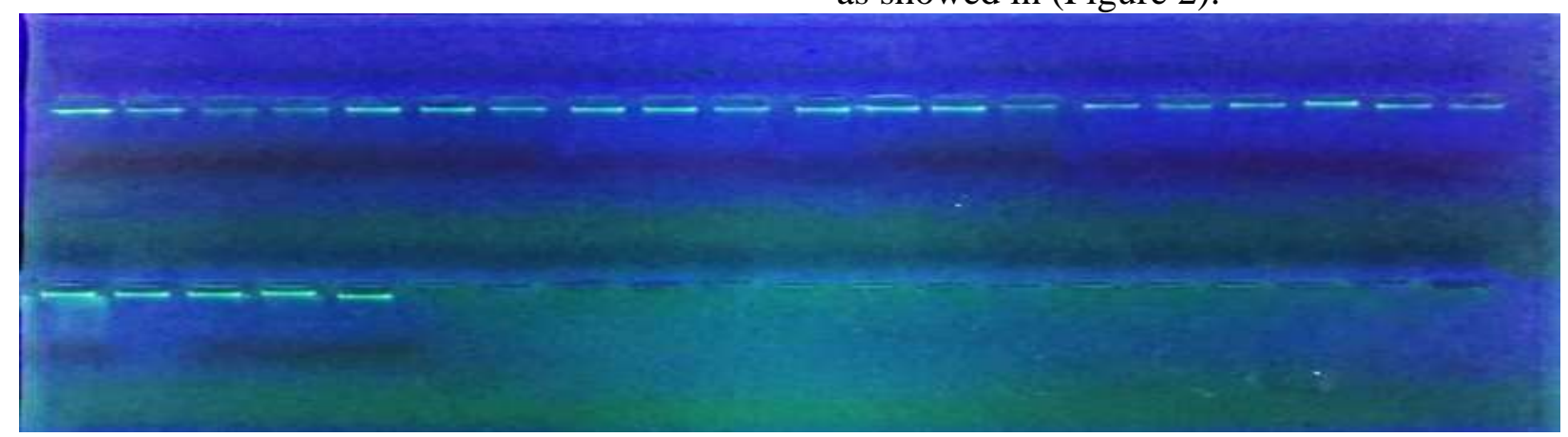

Figure 2. Gel electrophoresis of genomic DNA extraction from blood, Voltage 60, Gel concentration: $0.8 \%$ agarose, Time: $1 \mathrm{~h}$

The PCR results revealed that 5 samples found positive for Babesia spp. with 441 bp using first primer and 4 samples found positive for
Babesia spp. with (751) bp using second primer as demonstrated in (Figure 3,4).

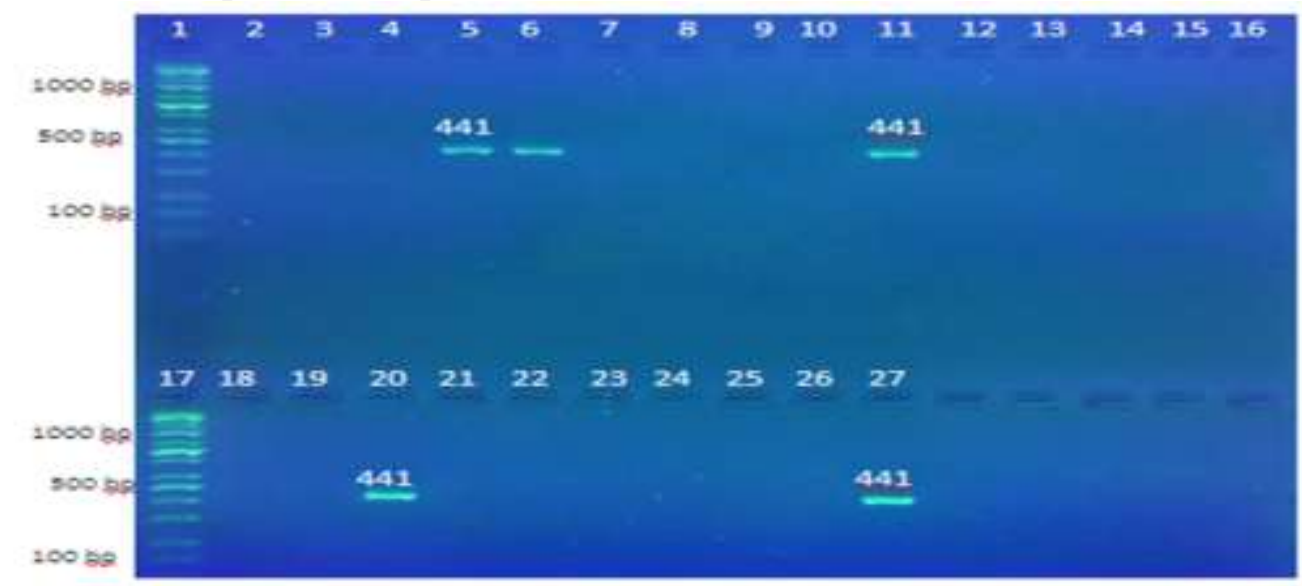

Figure 3. lines 1, 17: molecular marker (100bp); lines 5, 6, 11, 20 and 27 are positive Babesia spp. samples (441 bp); other lines were negative samples. The product was electrophoresis on $1.5 \%$ agarose at 75 volt for 1.5 hours

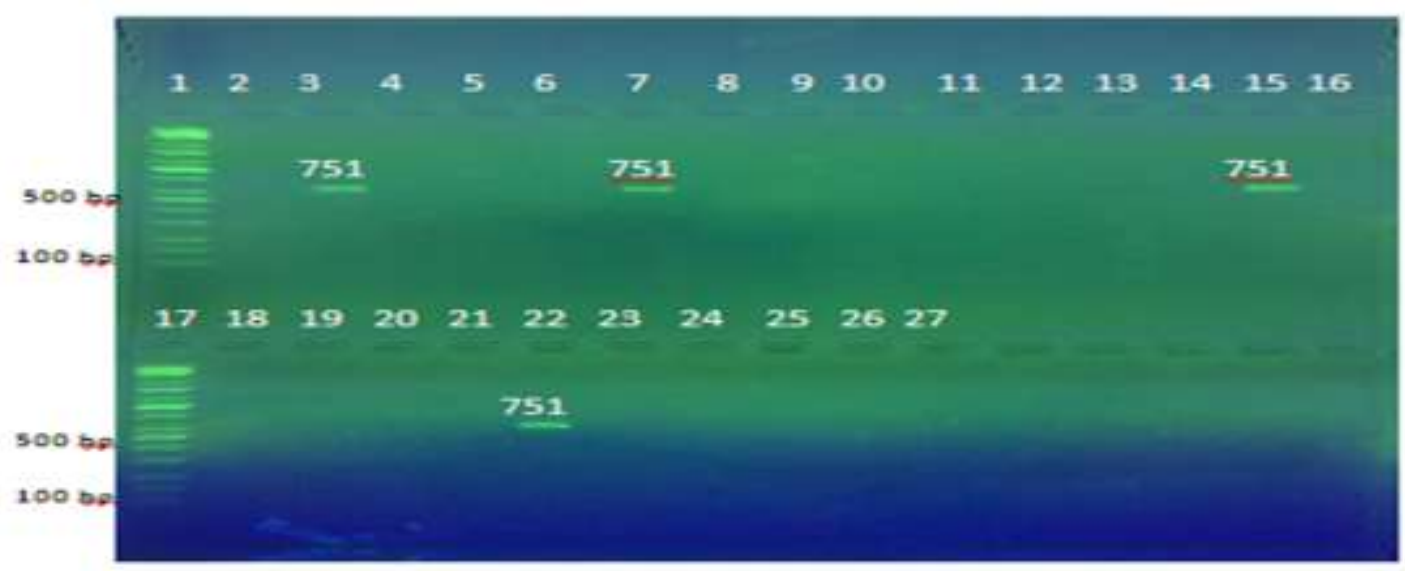

Figure 4. lines 1, 17: molecular marker (100bp); lines 3, 7, 15 and 22 are positive Babesia spp. samples (751 bp); other lines were negative samples. The product was electrophoresis on $1.5 \%$ agarose at 5 volt $/ \mathrm{cm}^{2} .1 .5$ hours 
In total, 9 PCR products were sequined and deposited in GeneBank in accession numbers; MK350319, MK346272, MK346273, MK346274, MK36275, MK346276, MK346277, MK346278 and MK350318

\section{Phylogenic Analysis}

The result of sequencing revealed that 5 PCR products were (MK350319, MK346272, MK346273, MK346274 and MK36275) belongs to T. equi isolates, while (MK346276, MK346277, MK346278 and MK350318) belongs to $B$. caballi. Comparative sequence analysis mounted a low genetic variation (0.035) among all comparison isolates and revealed $99-100 \%$. Sequences result showed that MK36275 Iraqi isolate was 100\% identity to Spain isolate, MK346273 and MK346274 Iraqi isolates showed $100 \%$ identity between each other, while MK350319 and MK346272 Iraqi isolates showed 99\% identity among all isolates as clarified in (Figure 5).

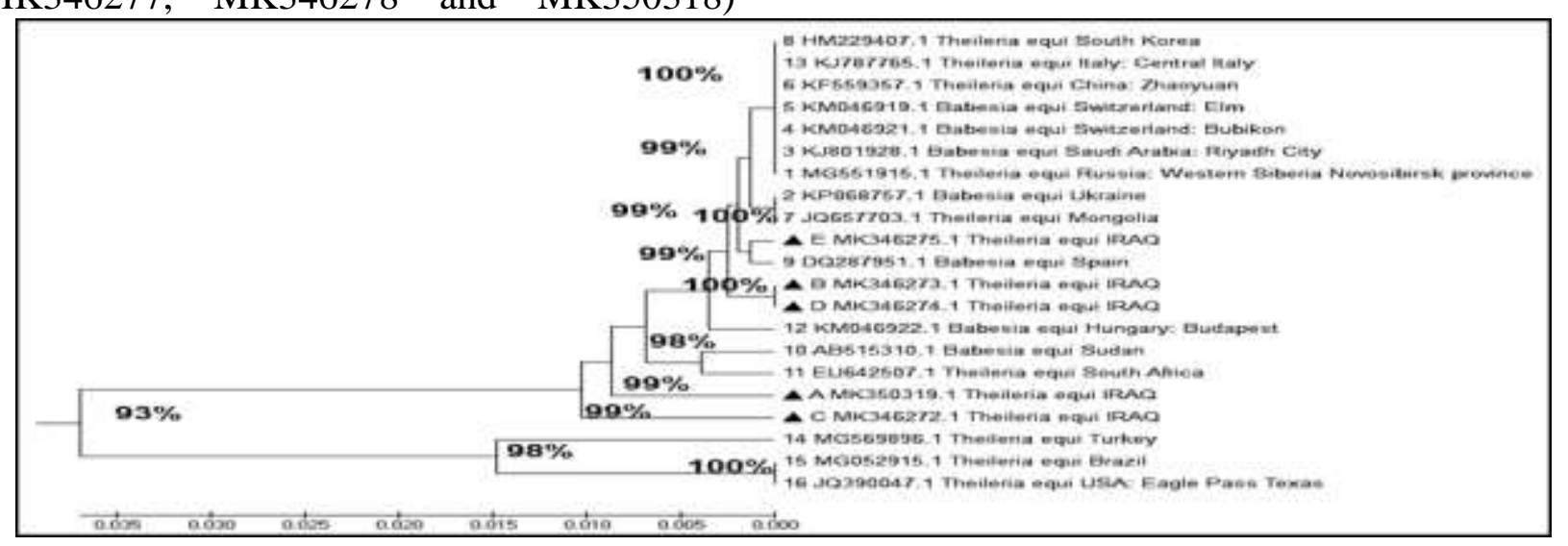

Figure 5. Theileria equi Phylogenetic analysis.

The phylogenetic relationships mounted a low genetic variation (0.05) among all comparison isolates of the $B$. caballi of Iraqi isolates and other B. caballi isolates published achieved from GenBank showed $100 \%$ identity among
MK346276, MK346277, MK346278 and MK350318 Iraqi isolates and clarified that South Africa and Spain are more close to them as demonstrated in (Figure6).

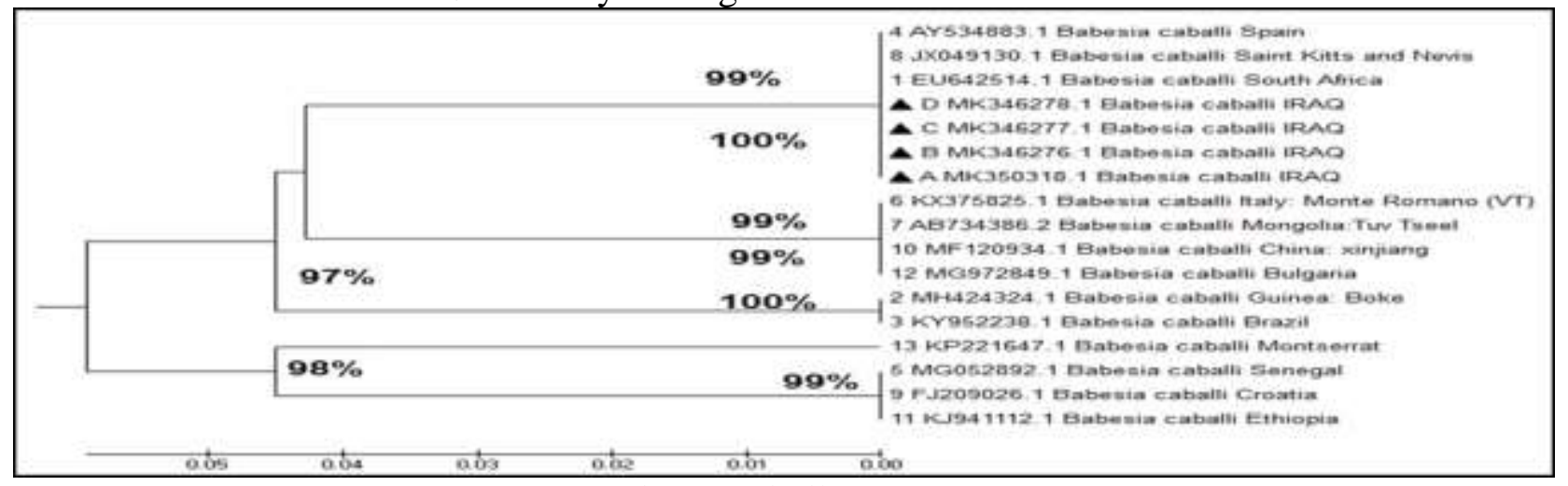

Figure 6. Babesia caballi phylogenetic tree.

Molecular blood examination for study group animals using PCR reaction depending on oligonucleotide primers specific for Equine piroplasmosis revealed that $36 \%$ were positive

for the presence of piroplasmid DNA, while traditional method depending on Giemsa stain were found $8 \%$ positive, with significant $(\mathrm{P}<0.01)$ as showed in (Table4).

Table 4. Comparison between the results of microscopic examination and molecular method and differentiate between species

\begin{tabular}{|ccccccc|}
\hline Technique & $\begin{array}{c}\text { No. of blood } \\
\text { samples }\end{array}$ & $\begin{array}{c}\text { No. infected } \\
\text { animals }\end{array}$ & $\%$ & Chi-Square $\left(\chi^{2}\right)$ & $\begin{array}{c}\text { B. caballi } \\
\text { Infection }\end{array}$ & $\begin{array}{c}\text { T. equi } \\
\text { Infection }\end{array}$ \\
\hline $\begin{array}{c}\text { Microscopic } \\
\text { examination } \\
\text { PCR }\end{array}$ & 25 & 2 & 8 & $8.263 * *$ & 0 & 0 \\
& 25 & 9 & $\begin{array}{c}36 \\
* *(\mathbf{P}<0.01) .\end{array}$ & 4 & 5 \\
\hline
\end{tabular}


The result of microscopic examination comparison with PCR method revealed that PCR method has high rate of infection than microscopic examination and that results agrees with $(1,13)$. The current study revealed low sensitivity of Giemsa stained blood smear examination test to detect few level of parasitemia when compared to the PCR technique.Our molecular assay study proved using two different primers to diagnosis of $B$. caballi and T. equi in Equine, and can also be used to detect these parasites in animals suspected carrier and that deal with El-Naga and Barghash, (6) results indicated that molecular method could detected DNA of Theileria and Babesia subspecies present and it an accurate technique. Another previous molecular biological assay studies improved many genetic haemoparasites detection $(3,15)$, Sibeko et al. (22) indicted high sensitivity and specificity of PCR to detected Babesia and Theileria spp. than serological test.

The study results demonstrated $B$. caballi and T. equi occurrence and circulation in Equine, and clarified that the ribosomal RNA genes stability makes them an attractive target for species discrimination of this parasite by molecular assay. Additionally, PCR technique followed by phylogenic tree analysis good methods for detection and identification of genetic variants.

\section{REFERENCES}

1.Bahrami, S.; A.R. Ghadrdan, S.M. Mirabdollahi, and M.R. Fayed, 2014. Diagnosis of subclinical equine theileriosis in center of Iran using parasitological and molecular methods. Trop Biomed. 31: 110 117

2. Battsetseg, B.; S. Lucero, and S. Xuan, 2002. "Detection of natural infection of Boophilus microplus with Babesia equi and Babesia caballi in Brazilian horses using nested polymerase chain reaction," Vet Parasitol. 107: 351-357

3. Caccio, S.; C. Camma, M. Onuma, and C. Severini, 2000. The beta-tubulin gene of Babesia and Theileria parasites is an informative marker for species discrimination. Int J Parasitol. 30: 1181-1185

4. Casati, S.; H. Sager, L. Gern, and J.C. Piffaretti, 2006. Presence of potentially pathogenic Babesia sp. for human in Ixodes ricinus in Switzerland. Ann. Agric. Environ. Med. 13: 65-70

5. Coles, E.H. 1986.Veterinary Clinical Pathology, 4thed. WB. Saunders Co., Philadelphia. pp: 512-513

6. El-Naga, T.R.A. and S.M. Barghash, 2016. Blood Parasites in Camels (Camelus dromedarius) in Northern West Coast of Egypt. J. Bacteriol. Parasitol. 7:258-259

7. Garba, U. M.; A.K. B.Sackey, L. B. Tekdek, R.I.S. Agbede, and M. Bisalla, 2011.Clinical Manifestations and Prevalence of Piroplasmosis in Nigerian Royal Horses. J. Vet. Adv. 1: 11-15

8. Ibrahim, A.K.; I.S. Gamil, A.A. Abd-El Baky, M.M. Hussein, and A.A. Tohamy, 2011. Comparative Molecular and Conventional Detection Methods of Babesia equi (B. equi) in Egyptian Equine. Glob. Vet. 7: 201-210

9. Mahmoud, M.S.; N.T.A. El-Ezz, S. AbdelShafy, S.A. Nassar, A.H. El Namaky, W.K. Khalil, D. Knowles, L. Kappmeyer, M.G. Silva, and C.E. Suarez, 2016. Assessment of Theileria equi and Babesia caballi infections in equine populations in egypt by molecular, serological and hematological approaches. Parasite Vectors. 9: 260-267

10. Malekifard, F.; M. Tavassoli, M. Yakhchali, and R. Darvishzadeh, 2014. Detection of Theileria equi and Babesia caballi using microscopic and molecular methods in horses in suburb of Urmia, Iran .Vet Res 5: $129-133$

11. Maniatis, T.; E. F. Fritsch, and J. Sambrook, 1982. Molecular cloning: a laboratory manual, Cold Spring Harbor laboratory, N.Y.8: 311-16

12. Mekibib, B. M. Manegerew, A. Tadesse, F. Abuna, B. Megersa, A. Regassa, S, Mekuria, and R. Abebe, 2010. Prevalence of hemoparasites and associated risk factors in working donkeys in Adigudem and Kwiha districts of Tigray region, northern Ethiopia. J Anim Vet Adv 9:2249-2255

13. Moatloang, M. Y. ; O. M . M. Thekisoe, A. Alhassan, M. Bakheit, M. P. Motheo, F. E. S. Masangane, M.L. Thibedi, N. Inoue, I. Igarashi. C. Sugimoto, and P. A. Mbati, 2008. Prevalence of Theileria equi and Babesia caballi infections in horses belonging to resource-poor farmers in the north-eastern free 
state province,South Africa. Onderstepoort. J. Vet. Res. 75:141-146

14. Mujica, F.; C. Massard, M.P. Franque, A. Coronado, M. Forlano, and C. Suarez, 2004."Grado de infección y mortalidad en la garrapata del caballo Anocentor nitens (Acari: Ixodidae) naturalmente infectada porel protozoa Babesia caballi (Apicomplexa: Babesiidae)," Revista Científica.14: 440-443

15. Nagore, D.; J. Garcia-Sanmartin, A.L. Garcia-Perez, R.A. Juste, and A. Hurtado, 2004. Detection and identification of equine Theileria and Babesia species by reverse line blotting: epidemiological survey and phylogenetic analysis. Vet Parasitol. 123:4154

16. Oosthuizen, M.C.; Z. Erich, E. Nicola, S. Collins, T. Milana, and L. Banie, 2008. Identification of a Novel Babesia sp. from a Sable Antelope. J.Clinc Microbiol. 46: 22472251

17. Rampersad, J.; E. Cesar, M. D. Campbell, M. Samlal, and D. Ammons, 2003. "A field evaluation of PCR for the routine detection of Babesia equi in horses," Vet Parasitol. 114: 81-87

18. Razmi, G.R.; A. Naghibi, and M.R. Aslani, 2002. An epidemio-logical study on ovine babesiosis in the Mashhad suburb area, province of Khorasan, Iran. Vet Parasitol . 108: 109-115

19. Salim, B.O., S.M. Hassan, M.A. Bakheit, A. Alhassan, I. Igarashi, P. Karanis, Abdelrahman, M.B. Diagnosis of Babesia caballi and Theileria equi infections in horses in Sudan using ELISA and PCR.. Parasitol Res. 103: 1145-1150

20. Sambrook, J. and D.W. Russell, 2001. In vitro mutagenesis using double stranded DNA templates: selection of mutants with DpnI. In: Molecular cloning, a laboratory manual. Cold Spring Harbor, NY: Cold Spring Harbor Laboratory Press; $13.19-13$
21. SAS. 2012. Statistical Analysis System, User's Guide. Statistical. Version 9.1. SAS. Inst. Inc. Cary. N.C. USA

22. Sibeko, K.P.; M.C. Oosthuizen, N.E. Collins, D. Geysen, N.E. Rambritch, A.A. Latif, H.T. Groeneveld, F.T. Potgieter, and J.A.W. Coetzer, 2008. Development and evaluation of a real-time polymerase chain reaction test for the detection of Theileiria parva infections in Cape buffalo (Syncerus caffer) and cattle. Vet Parasitol. 155:37-48.

23. Sigg, L. ; V. Gerber, B. Gottstein, M.G. Doherr, and C.F. Frey, 2010. Seroprevalence of Babesia caballi and Theileria equi in the Swiss horse population Parasitol Int. 59:313317.

24. Slivinska, K.; B. Víchová, J. Werszkoc, T. Szewczyk, Z. Wróblewski, and B. Petko, 2016. Molecular surveillance of Theileria equi and Anaplasma phagocytophilum infections in horses from Ukraine, Poland and Slovakia. Vet Parasitol. 215:35-37

25. Sumbria, D.; L. Das Singla, and A. Sharma, 2016. Theileria equi and Babesia caballi infection of equids in Punjab, India: a serological and molecular survey.Trop Anim Health Prod. 48:45-52

26. Turaki, U. A.; H. A. Kumsha, A.A. Biu, and P. B. Bokko, 2014. Prevalence of Piroplasmosis amongst local horses in Northeastern Nigeria. Vet Sci. 7: 4-7

27. Walker, A.; A. Bouattour, J.L. Camicas, A. Estrada-Pena, I.G. Horak, A.A. Latif, R.G. Pegram, and P.M. Preston, 2003. Ticks of domestic animals in Africa: A guide to identification of species, 1st ed. Bioscience Reports, Edinburgh, Scotland, UK, pp. 114200

28. Zobba, R.; M. Ardu, S. Niccolini, B. Chessa, L. Manna, R. Cocco and M.L.P. Parpaglia, 2008. Clinical and laboratory finding in equine piroplasmosis. J. Equine Vet. Sci. 28: 301-308 